\title{
Method of MSW landfill reclamation using waste conversion products
}

\author{
N.O. Milyutina \\ Postgraduate student, Saint Petersburg State University, Saint Petersburg, Russia \\ N.A. Averianova \\ PhD, Chief process engineer, JSC Avtopark №1 «Spectrans», Saint Petersburg, Russia \\ E.S. Velikoselsksya \\ Ecologist, LLC Novyj Svet.EKO, Saint Petersburg, Russia \\ D.M. Malyuhin \\ Deputy general Director, LLC Novyj Svet-EKO, Saint Petersburg, Russia \\ N.A. Politaeva \\ DSc, Professor, Peter the Great Saint Petersburg Polytechnic University, Saint Petersburg, Russia
}

\begin{abstract}
Mostly, municipal solid waste in Russia is disposed of in landfills. It is known that the main problems in landfill reclamation are the leachate purification and the application of a fertile layer. The most commonly used technology of leachate purification nowadays is reverse osmosis, but the result of this method are two substances: clean water and new waste - concentrate. The creation of a fertile layer is related to the destruction of natural land. A new method of leachate utilization without the generation of new waste is presented in this paper. Also, it is proposed to use the biological potential of the organic waste fraction to create a fertile layer. As a result, a resource-saving scheme for landfill reclamation using waste potential has been developed.
\end{abstract}

\section{INTRODUCTION}

About 35 to 40 million tons of municipal solid waste (MSW) are annually generated in Russia. Only $4-5 \%$ of them are sent for recycling while the remaining waste is disposed of in landfills and dumps. However, this type of waste management is the least preferred according to the hierarchy of accepted methods (Wilson, 1999, Umanets, 2014, Yousefloo, 2020).

Under the influence of biological, physical and chemical factors, the processes of substance transformation occur in the body of MSW landfill. The formed leachate and biogas determine the polluting effect of MSW landfills on the environment (Gourc, 2010, Popovych, 2020, Wilson, 1999). MSW landfills remain sources of pollutants despite the observance of protective measures on the spot. Problems associated with the emission of MSW transformation products remain even after the closure of landfills. Therefore, it is necessary to conduct landfill reclamation.

Reclamation is a combination of engineering, technical and sanitary-hygienic measures that allow to restore the ecological balance of the environment near landfills. Reclamation is divided into technical and biological stages. The technical stage includes the selection of technologies for collecting, purifying and utilizing biogas and leachate as well as slopes formation and application of recultivation layers, the final of which is a fertile soil layer. The biological stage is a set of agrotechnical and phytomeliorative measures to restore the territory of closed 
landfills. The main economic and environmental problems in landfill reclamation are related to purification and disposal of the leachate, as well as the creation of a fertile layer (Lassini, 1999, Weng, 2015).

\section{LITERATURE REVIEW}

Most of the MSW landfills currently operating in Russia are not equipped with a local leachate treatment station. The most common way to reduce leachate during landfill operation is its recirculation. However, this does not solve the problem completely and becomes impossible to use after landfill reclamation (He, 2005). Therefore, an important issue in the technical stage of reclamation is the selection and installation of a treatment plant.

The main methods for purifying the leachate can be divided into biological (aerobic and anaerobic), mechanical (sedimentation, filtration, separation) and physicochemical (coagulation, flocculation, flotation, ion exchange, sorption, micro and ultrafiltration, reverse osmosis, ozonation, electrolysis, ultraviolet radiation) (Henze, 1995, Renou, 2008, Salem, 2008, Silva, 2004, Trebouet, 2001). To achieve a high degree of purification, a combination of these methods is necessary. The most commonly used technology nowadays is reverse osmosis with preliminary mechanical and/or physicochemical treatment of the leachate. The permeate (purified water) obtained as a result of such a purification scheme corresponds to the quality required for its discharge to surface water (Renou, 2008). On the other hand, the use of reverse osmosis leads to the formation of a concentrate representing $25-50 \%$ of the raw leachate, which is itself a new form of waste that must be disposed of.

The second problem of the technical stage of reclamation is applying the fertile layer which is necessary for the realization of the biological stage. The creation of this reclamation layer is an environmental and economic problem due to the shortage of soil. It is estimated that up to $10000 \mathrm{~m}^{3}$ of fertile soil is required for the reclamation of 1 hectare of landfill, which corresponds to the destruction of 5 hectares of natural land. It should be kept in mind that when using mineral loam soils as a recultivation layer, the processes of humus formation occur very slowly. In fact, in 15 years, only $1.5-2 \mathrm{~cm}$ of a continuous humus horizon is formed. In order to save natural resources and accelerate biological processes during reclamation work, the soil can be replaced with organogenic substrates from MSW (Ilinykh, 2015, Awasthi, 2020). The high biological potential of these substrates that are due to their rich plant nutrients and humified organic matter content is universally recognized (Bolan, 2013, Gauhey, 1953).

Waste composting can be carried out in biodrums or in storage pits by the field method. Before composting, it is necessary to sort waste. The activation of biological processes based on the microflora contained in the compostable mass is ensured by aeration using a compost turner (Werf, 2000). The rotating shaft of the turner mixes the mass of the storage pits in such a way that it keeps its trapezoidal shape.

The processes that occur during composting of waste can be divided into 3 phases. The first is characterized by the rapid reproduction of mesophilic microorganisms at an optimal temperature of $20-35^{\circ} \mathrm{C}$. Easily biodegradable organic compounds, mainly found in food waste (carbohydrates, organic acids, proteins), serve as an energy source for bacteria. As a result of their vital activity, thermal energy is released, which contributes to the heating of the composted material to a temperature of $50{ }^{\circ} \mathrm{C}$. In the second phase, this increase in temperature creates favorable conditions for the development of thermophilic microorganisms, which, as a result of their vital activity, increases even more the heat generation and accelerate the decomposition of organic substances. The temperature of the composted material rises to $55-60{ }^{\circ} \mathrm{C}$. The third phase is a slow drop in temperature, indicating the exhaustion of easily decomposable organic compounds. At this stage, a part of the thermophilic microflora dies and the other part goes into a state of spore formation. The mesophilic microflora begins to multiply again due to its more diverse and powerful enzymatic system, with the help of which more stable organic compounds (fiber, lignin) are decomposed. Antibiotic substances with bactericidal properties produced by the biothermal process inhibit the development or cause the death of pathogenic microflora (zhu, 2019, Jain, 2020, Ilinykh, 2015, Liwarska-Bizukoje, 2001). 


\section{METHODS AND MATERIALS OF INVESTIGATION}

The objects of this study consisted of the leachate from one of the MSW landfills of the Leningrad Region, the stabilized leachate and the technogenic soil. The leachate stabilized by solidification was obtained at different periods of time (six samples). The technogenic soil (ten samples) was produced by field composting of sorted municipal solid waste.

In the course of this research, the heavy metals content and agrochemical indicators of the studied objects have been determined. The analysis of the heavy metals content was carried out by Inductively Coupled Plasma Optical Emission Spectroscopy (ICP OES). The toxicity of the stabilized leachate was determined by biotesting. The organic carbon content was determined by the Tyurin method. The active forms of phosphorus were determined by the Denizha colorimetric method after effectuating a Kirsanov extraction. The analysis of the active forms of potassium was carried out using a PAZh-2 flame analyzer from a Kirsanov extract. The active forms of nitrogen were determined by the colorimetric method; nitrate nitrogen with disulfophenolic acid and ammonium with the Nessler reagent.

\section{THE RESULTS AND DISCUSSION}

\subsection{Leachate utilization}

In the course of this research, a new technology for the leachate utilization based on a change in the aggregation state of a liquid into a solid product has been developed. This new product is obtained by the mechanical mixing of the leachate with special reagents. The process is divided in two main stages: the first stage consists of water coagulation, the result of which is the basis for the activation of the second stage - hardening of the mixture due to the formation of mineral components. Various known compounds widely used for MSW leachate purification (Trebouet, 2001) serve as coagulation activators in the present technology. The selection of a particular coagulant depends on the chemical composition of the raw leachate. The main binder additive is the mineral residue from the burning of oil shale in thermal power plants.

The high porosity of the particles of the binder additive leads to the sorption of neutralization reaction soluble products and other soluble impurities of the leachate. Also, as a consequence of chemical reactions, poorly soluble humates of heavy metals are formed. During the mixing of the components, gases are released and are sent to a gas purification filter based on fibrous composite material. The composition of the resulting gases includes nitrogen dioxide $\left(\mathrm{NO}_{2}\right)$, carbon monoxide $(\mathrm{CO})$, hydrogen sulfide $\left(\mathrm{H}_{2} \mathrm{~S}\right)$, nitric oxide $(\mathrm{NO})$ and methane $\left(\mathrm{CH}_{4}\right)$. A plastic paste-like mass of material obtained after mixing components is formed, which hardens and gains strength within 21 days.

The chemical composition of the leachate depends on a number of factors. The main ones are the morphological composition of the deposited waste and the landfill stage of life, which corresponds to a certain stage of biochemical and physicochemical transformation of the waste. The leachate is conditionally divided into "young" and "old" according to its chemical composition. The "young" leachate is formed at the first stages of waste decomposition in the acetogenic phase after the 2-7 years of waste storage. The "old" leachate is formed at the methanogenic stages (salem, 2008). Depending on the amount of organic carbon (COD and BOD), basic anions and heavy metals (HM) in the leachate, the ratio of the main components when converting the leachate to a solid product can be varied for obtaining a high-quality product.

The studied leachate was determined as "old" and the appropriate ratio of components and mixing have been selected, after which, a product of solidification was obtained. The content of the active forms of HM in the new product is presented in Table 1.

The total content of HM in this product is presented in Table 2. These concentrations represent the average contents in the six samples.

From the data obtained, it follows that the content of heavy metals in the solid product does not exceed permissible concentrations for settlement soils. 
Table 1. Active form of heavy metals content in the solid product.

\begin{tabular}{lll}
\hline Heavy metal (active form) & Concentration, $\mathrm{mg} / \mathrm{kg}$ & LOC*, mg/kg \\
\hline $\mathrm{Ni}^{2+}$ & $1.1 \pm$ & 4.0 \\
$\mathrm{Co}^{2+}$ & $<1.0$ & 5.0 \\
$\mathrm{Cu}^{2+}$ & $<1.0$ & 3.0 \\
$\mathrm{Mn}^{2+}$ & $28.0 \pm 4,2$ & 80.0 \\
$\mathrm{Cr}^{3+}$ and $\mathrm{Cr}^{6+}$ & $1.7 \pm$ & 6.0 \\
$\mathrm{~Pb}^{2+}$ & $2.7 \pm$ & 6.0 \\
$\mathrm{Zn}^{2+}$ & $5.3 \pm$ & 23.0 \\
\hline
\end{tabular}

* Level of concern from the Hygienic Standards 2.1.7.2041-06.

Table 2. Total heavy metals content in the solid product.

\begin{tabular}{lll}
\hline Heavy metal (total) & Concentration, $\mathrm{mg} / \mathrm{kg}$ & $\mathrm{LOC}, \mathrm{mg} / \mathrm{kg}$ \\
\hline $\mathrm{Hg}$ & $0.068 \pm 0.0078$ & 2.1 \\
$\mathrm{As}$ & $10.02 \pm 0.83$ & 10.0 \\
$\mathrm{Ni}$ & $3.60 \pm 0.32$ & 80.0 \\
$\mathrm{Co}$ & $1.43 \pm 0.14$ & - \\
$\mathrm{Cu}$ & $2.21 \pm 0.17$ & 132.0 \\
$\mathrm{Mn}$ & $72.0 \pm 4.3$ & 1500 \\
$\mathrm{Cr}$ & $6.02 \pm 0.54$ & - \\
$\mathrm{Pb}$ & $7.98 \pm 0.61$ & 130.0 \\
$\mathrm{Zn}$ & $16.0 \pm 1.1$ & 220.0 \\
$\mathrm{Cd}$ & $0.162 \pm 0.015$ & 2.0 \\
\hline
\end{tabular}

* Level of concern from the Hygienic Standards 2.1.7.2511-09.

The toxicological studies carried out on white rats and guinea pigs as well as the bioassays realized on Daphnia magna Straus and Chlorella vulgaris did not show any toxic effects of the product (Table 3,4$)$.

The resulting solid product is proposed to be used during reclamation as a leveling layer (when grinded to a fraction of 1-5 mm diameter), and also as a drainage layer under a fertile soil (when crushed to a fraction of 20-40 mm diameter). Moreover, this product can be used as an inert material when refilling waste during the operation of the MSW landfills and for building roads to the facility. Thus, the leachate is converted into a solid product without receiving new waste and can be implemented directly at its production site.

\subsection{Creation of the fertile layer}

In the course of this work, it was confirmed that 180 days are needed for obtaining the product of waste field composting in Saint-Petersburg climate. However, the use of additional biological additives can reduce the ripening time of the product, i.e. the technogenic soil, to 90 days. Currently, due to the relevance of using the potential of MSW landfills, various modifications of biological additives with antimicrobial effects have been designed to accelerate the decomposition of organic substances. Tests on the influence of several Russian brands of biological additives on the raw mass of sorted waste have revealed a more rapid humus formation and, consequently, a faster ripening of technogenic soil.

The chemical composition of the technogenic soil obtained after field composting of sorted waste is presented in Table 5.

According to the obtained data, the technogenic soil is a very agrochemically favorable substrate for plant growth and significantly exceeds the sod-podzolic soil in terms of nutrient content. The total content of heavy metals does not exceed the normative indicators for composts 
Table 3. Toxicological studies of the new solid product on laboratory animals.

\begin{tabular}{|c|c|c|c|}
\hline Indicator & Units & Research results & $\begin{array}{l}\text { Russian normative document on } \\
\text { the research method }\end{array}$ \\
\hline $\begin{array}{l}\text { Acute toxicity by intragas- } \\
\text { tric gavage } \mathrm{DL}_{50} \text { (white } \\
\text { rats) }\end{array}$ & $\mathrm{mg} / \mathrm{kg}$ & $\mathrm{DL}_{50}>5000$ & $\begin{array}{l}\text { Instruction 1.1.11-12-35-2004 } \\
\text { "Experimental research require- } \\
\text { ments for primary toxicological } \\
\text { evaluation and hygienic regula- } \\
\text { tion of substances" }\end{array}$ \\
\hline $\begin{array}{l}\text { Inhalation hazard by static } \\
\text { inhalation inoculation, } \\
\text { (n.c.), exposure for } 2 \text { hours, } \\
\text { (white rats) }\end{array}$ & - & $\begin{array}{l}\text { The volatile components did not } \\
\text { cause irritation of the mucous } \\
\text { membranes of the eyes and } \\
\text { upper respiratory tract. The } \\
\text { death of animals was not } \\
\text { recorded. }\end{array}$ & $\begin{array}{l}\text { "Recommendations for prelim- } \\
\text { inary assessment of chemical } \\
\text { substance toxicity by accelerated } \\
\text { method" }\end{array}$ \\
\hline $\begin{array}{l}\text { Skin-irritant effect (white } \\
\text { rats) } \\
\text {-singly } \\
\text {-repeatedly }\end{array}$ & $\begin{array}{l}\text { points } \\
\text { points }\end{array}$ & $\begin{array}{l}0 \\
0\end{array}$ & $\begin{array}{l}\text { Methodical guidelines №2102-79 } \\
\text { "Assessment of the impact of } \\
\text { harmful chemical compounds } \\
\text { on the skin and the justification } \\
\text { of extremely acceptable levels of } \\
\text { skin contamination" }\end{array}$ \\
\hline $\begin{array}{l}\text { Irritation of the mucous } \\
\text { membranes of the eyes } \\
\text { (guinea pigs) }\end{array}$ & points & 0 & $\begin{array}{l}\text { Methodical guidelines № } 2196- \\
80 \text { "Setting up studies of irritat- } \\
\text { ing properties and justification } \\
\text { of maximum permissible con- } \\
\text { centrations of selectively acting } \\
\text { irritating substances in the air of } \\
\text { the working area" }\end{array}$ \\
\hline
\end{tabular}

Table 4. Toxicological studies of the new solid product by bioassays.

\begin{tabular}{|c|c|c|c|c|c|c|c|}
\hline Indicator & Units & Resec & ch res & & & $\begin{array}{l}\text { Permissible } \\
\text { level }\end{array}$ & $\begin{array}{l}\text { Russian normative document on the } \\
\text { research method }\end{array}$ \\
\hline \multirow{5}{*}{$\begin{array}{l}\text { Dilution of the } \\
\text { extract tested on } \\
\text { the hydrobionts: } \\
\text {-without dilution } \\
\text {-control } \\
\text { Sensitivity of } \\
\text { Chlorella at mul- } \\
\text { tiple rates of } \\
\text { dilution: } \\
\text {-without dilution } \\
\text {-control }\end{array}$} & $\%$ & $24 \mathrm{~h}$ & $48 \mathrm{~h}$ & $72 \mathrm{~h}$ & $96 \mathrm{~h}$ & \multirow[t]{3}{*}{$\mathrm{A} \leq 10$} & \multirow{5}{*}{$\begin{array}{l}\text { FR 1.39.2007.03222 "Methods for } \\
\text { determining water toxicity and water } \\
\text { extracts from soil, sewage sludge, } \\
\text { waste on mortality and fertility } \\
\text { changes of Daphnia" } \\
\text { FR 1.39.2015.20001 "Method of the } \\
\text { measurement of the optical density of } \\
\text { cultures of Chlorella algae for the } \\
\text { determination of drinking, fresh, nat- } \\
\text { ural and waste water, water extracts } \\
\text { from soil, sewage sludge, and waste } \\
\text { toxicity" }\end{array}$} \\
\hline & & 0 & 0 & 0 & 0 & & \\
\hline & & 0 & 0 & 0 & 0 & & \\
\hline & $\%$ & $+9,6$ & & & & $-30<\mathrm{I}<+20$ & \\
\hline & & 0 & & & & & \\
\hline
\end{tabular}

from MSW. It should be noted that the bioavailable forms of HM are even less (KabataPendias, 2001). Despite that it is not planned to use the plants that naturally sprouted on the technogenic soil for feed, results have shown that these plants were within the standards of fodder crops of farm animals. 
Table 5. Chemical composition of the technogenic soil.

\begin{tabular}{lll}
\hline Elements & Concentration & Measurement units \\
\hline $\mathrm{C}$ total & $11.3 \pm 0.8$ & $\%$ \\
$\mathrm{~N}$ total & $0.54 \pm 0.07$ & $\%$ \\
$\mathrm{C}: \mathrm{N}$ & 20.9 & $\mathrm{unit}$ fraction \\
$\mathrm{N}-\mathrm{NH}_{4}$ (active form) & $22.4 \pm 1.3$ & $\mathrm{mg} / \mathrm{kg}$ \\
$\mathrm{N}-\mathrm{NO}_{3}$ (active form) & $31.2 \pm 2.5$ & $\mathrm{mg} / \mathrm{kg}$ \\
$\mathrm{P}$ (active form) & $343 \pm 31$ & $\mathrm{mg} / \mathrm{kg}$ \\
$\mathrm{K}$ (active form) & $339 \pm 20$ & $\mathrm{mg} / \mathrm{kg}$ \\
$\mathrm{Cu}$ (total) & $103 \pm 7$ & $\mathrm{mg} / \mathrm{kg}$ \\
$\mathrm{Zn}$ (total) & $208 \pm 9$ & $\mathrm{mg} / \mathrm{kg}$ \\
$\mathrm{Pb}$ (total) & $134 \pm 8$ & $\mathrm{mg} / \mathrm{kg}$ \\
$\mathrm{Cd}$ (total) & $3.32 \pm 0.28$ & $\mathrm{mg} / \mathrm{kg}$ \\
$\mathrm{Ni}$ (total) & $31.4 \pm 2.3$ & $\mathrm{mg} / \mathrm{kg}$ \\
$\mathrm{Mn}$ (total) & $4.50 \pm 0.39$ & $\mathrm{mg} / \mathrm{kg}$ \\
$\mathrm{Hg}$ (total) & $4.21 \pm 0.33$ & $\mathrm{mg} / \mathrm{kg}$ \\
As (total) & $2.13 \pm 0.17$ & $\mathrm{mg} / \mathrm{kg}$ \\
\hline
\end{tabular}

Thus, the technogenic soil obtained from the organic part of MSW is a rational and affordable method for replacing the fertile layer during reclamation.

\subsection{Use of the MSW potential in landfill reclamation}

During landfill reclamation, the following layers are used: a drainage layer to collect biogas, a waterproof layer to isolate the landfill body, a drainage layer to drain surface water and a fertile soil layer (Figure 1).

According to the obtained data, a method for landfill reclamation using the potential of waste coming to landfill is proposed. The product of the leachate solidification can serve as a drainage layer and technogenic soil as a fertile soil. The scheme of using waste transformation products during reclamation is presented in Figure 2.

Today, many landfills of the Russian Federation created at the end of the last century need to be reclaimed, and therefore the development of a landfill reclamation scheme using the potential of waste is relevant and opportune.

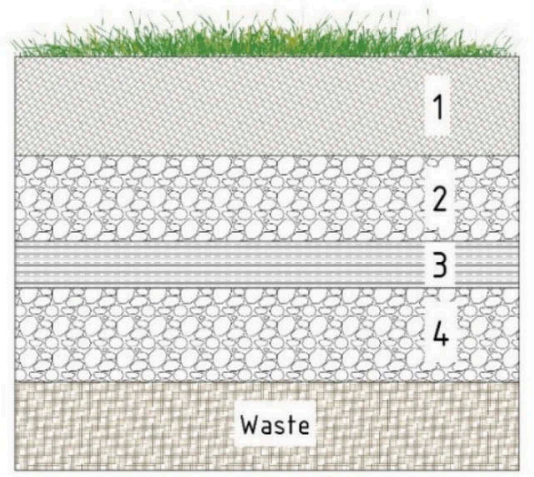

Figure 1. Reclamation layers of landfill: 1 - fertile layer, 2 - drainage layer for water, 3 - waterproof layer (clay), 4 - drainage layer for biogas. 


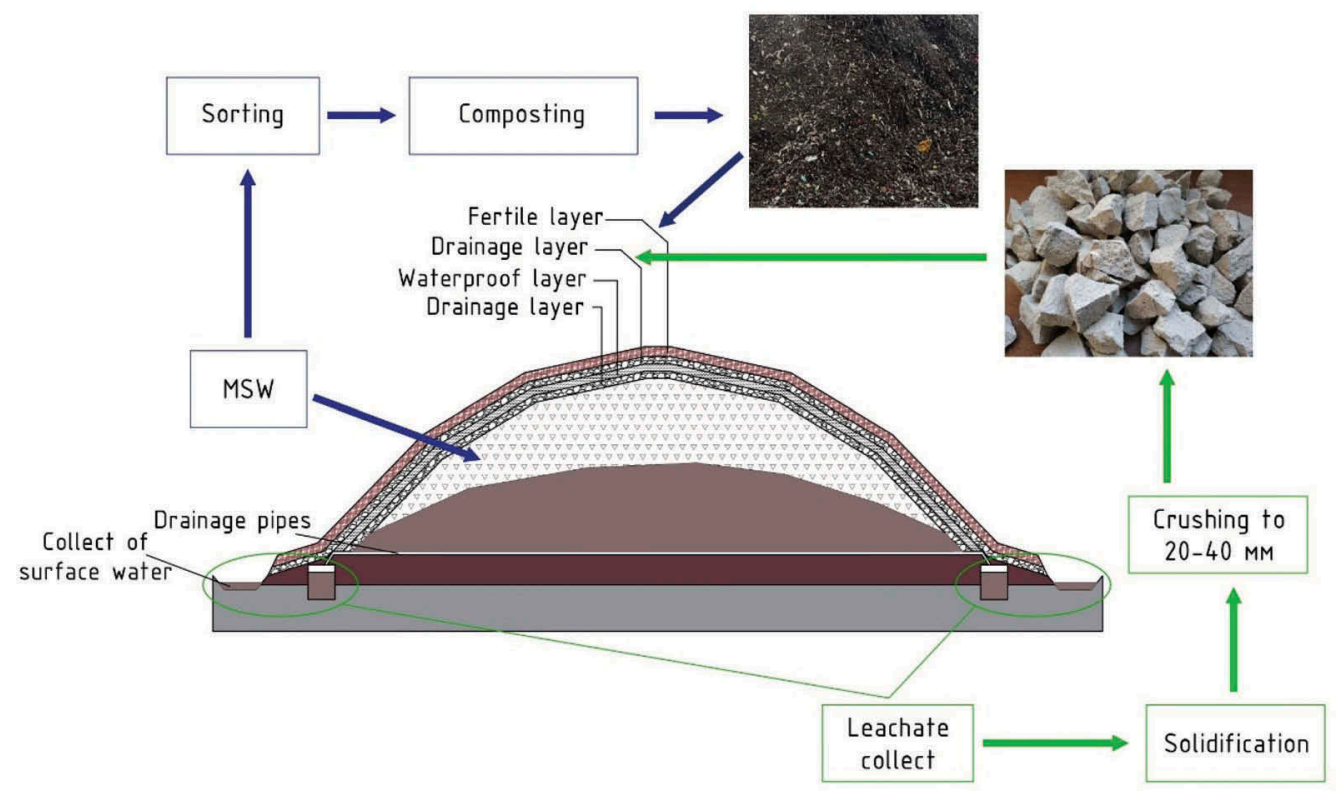

Figure 2. Scheme of using waste transformation products during reclamation.

\section{CONCLUSIONS}

1. A new method for the utilization of leachate has been developed, which allows the leachate to be converted into a solid product without generating new waste;

2. The content of heavy metals in the solid product did not exceed permissible concentrations for settlement soils and thus, does not represent a secondary source of pollution. Moreover, the toxicological studies confirmed the safety of this product;

3. It was confirmed that the technogenic soil obtained from the organic fraction of MSW has the necessary agrochemical parameters for its use as a fertile layer;

4. A resource-saving scheme for landfill reclamation using waste transformation products as reclamation layers was presented, which is economically and environmentally friendly.

\section{REFERENCES}

Awasthi, S.K., Sarsaiya, S., Awasthi, M.K. et al. 2020. Changes in global trends in food waste composting: Research challenges and opportunities. Bioresource Technology 299: 122555.

Bolan, N.S., Thangarajan, R., Seshadri, B. et al. 2013. Landfills as a biorefinery to produce biomass and capture biogas. Bioresource Technology 135: 578-587.

Gauhey, P., Golueke, C. 1953. Reclamation of Municipal Refuse by Composting. Berkeley: Univ. of Calif.

Gourc, J. P., Staub, M. J., Conte, M. 2010. Decoupling MSW settlement into mechanical and biochemical processes - Modelling and validation on large-scale setups. Waste Management 30: 1556-1568.

He, R., Shen, D., Wang, J., He, Y., Zhu, Y. 2005. Biological degradation of MSW in a methanogenic reactor using treated leachate recirculation. Process Biochemistry 40: 3660-3666.

Henze, M. 1995. Wastewater treatment. Biological and chemical processes. Berlin: Springier.

Ilinykh, G.V., Visman, YA.I., Slyusar, N.N., Korotaev, V.N. 2015. Municipal solid waste composition of the city of Perm, Russia: main changes over time. Intern. multidisciplinary scientific geoconference surveying geology and mining ecology management. Albena: SGEM.

Jain, M.S., Paul, S., Kalamdhad. A.S. 2020. Kinetics and physics during composting of various organic wastes: Statistical approach to interpret compost application feasibility. Journal of Cleaner Production 255: 120324.

Kabata-Pendias, A., Pendias, H. 2001. Trace elements in soils and plants. Boca Raton: CRC Press. 
Lassini, P., Sala, G., Sartori, F. 1999. Reclamation of old and new landfills and their integration with the invironment. Environmental impact, aftercare and remediation of landfills; 7 th intern. waste management and landfill symp. Sardinia: SIWMLS.

Liwarska-Bizukoje, E., Ledakowicz, S. 2001. Elemental balance for the biodegradation process of the organic fraction of municipal solid waste. Lodz: Technical university of Lodz.

Popovych, V., Telak, J., Telak, O. et al. 2020. Migration of hazardous components of municipal landfill leachates into the environment. Journal of Ecological Engineering 21: 52-62.

Renou, S., Givaudan, J.G., Poulain, S. et al. 2008. Landfill leachate treatment: review and opportunity. Journal of Hazardous Materials 150: 468-493.

Salem, Z., Hamouri, K., Djemaa, R., Allia, K. 2008. Evalution of landfill leachate pollution and treatment. Desalination 220: 108-114.

Silva, A. C., Dezotti, M., Sant'Anna, G. L. 2004. Treatment and detoxitation of a sanitary landfill leachate. Chemosphere 55: 207-214.

Trebouet, D., Schlumpf, J. P., Jaouen, P., Quermeneur, F. 2001. Stabilized landfill leachate treatment by combined physicochemicalnanofiltration process. Water Research 35: 2935-2945.

Umanets, V.N., Chusov, A.N., Umanets, E.V. 2014. Solution approach to historical pollution and accumulated production wastes. Ecology \& environmental protection: 607-614.

Weng, Y., Fujiwara, T., Houng, H.J. et al. 2015. Management of landfill reclamation with regard to biodiversity preservation, global warming mitigation and landfill mining: experiences from the AsiaPacific region. Journal of Cleaner Production 1041: 364-373.

Werf, P. 2000. Assessment and evaluation of outlets of compost produced from municipal waste. Wexford: Environmental Protection Agency.

Wilson, I.M., Garlick, C. 1999. Management and statistical analysis of landfill monitoring data. Environmental impact, aftercare and remediation of landfills; 7th intern. waste management and landfill symp. Sardinia: SIWMLS.

Yousefloo, A., Babazadeh, R. 2020. Designing an integrated municipal solid waste management network: A case study. Journal of Cleaner Production 244: 118824.

Zhu, L., Zhao, Y., Zhang, W. et al. 2019. Roles of bacterial community in the transformation of organic nitrogen toward enhanced bioavailability during composting with different wastes. Bioresource Technology 285: 121326. 